\title{
NON-PRODUCTIVITY OF AFLATOXIN BY JAPANESE INDUSTRIAL STRAINS OF ASPERGILLUS
}

\section{PRODUCTION OF FLUORESCENT SUBSTANCES IN RICE KOJI, AND THEIR IDENTIFICATION BY ABSORPTION SPECTRUM}

\author{
HIDEYA MURAKAMI, SUMIO TAKASE AND KENJI KUWABARA
}

Research Institute of Brewing, 2-6 Takinogawa, Kita-ku, Tokyo

(Received November 30, 1966)

When the Japanese industrial strains of Aspergillus were cultured on rice, they produced various kinds of fluorescent substance, most of which were similar, in excitation and emission maxima and in thin-layer chromatograms, to those produced in the shaking culture reported in Part I.

The aflatoxin productivity of 13 strains selected was further examined critically by culturing them on larger scales using two liters of the ADYE and MATELEs' medium (stationary culture) and/or one $\mathrm{kg}$ of polished rice, and by measuring the UV absorption spectrum of the spots separated by thin-layer chromatography. The results showed that the fluorescent spots produced by these strains were classified into nine patterns, and that none showed the same absorption spectrum as that of aflatoxin.

However, there still remains a question whether or not these fungi produce a trace amount of aflatoxin, which is rather difficult to prove by these cultivation methods. Since the presence of even a trace of aflatoxin in food should be avoided, it is desirable to find a correlation which may exist between the aflatoxin productivity of an organism and its mycological characters, by which the detection of afiatoxin-producing organism becomes easier and more accurate.

In the Japanese food industry, fungi are mainly cultured on various kinds of steamed materials such as polished rice, soy bean, wheat, and so on.

Recently a considerable amount of aflatoxin was found when an aflatoxin producer was grown on rice (1), which urged us to investigate carefully the productivity of aflatoxin by the Japanese industrial strains of Aspergillus.

In the present work, production of aflatoxin in rice koji by 160 strains of the yellow green-spored and 12 strains of the other Aspergilli, which were selected from 214 strains in a previous work (2), was examined by fluorometry and thin-layer chromatography. Then the productivity of aflatoxin by 13 important strains selected was further tested by growing them in a larger 
amount of medium and by using spectrophotometry after thin-layer chromatography.

\section{MATERIALS AND METHODS}

Preparation of koji. Eighty grams of polished rice, which had been steeped in water and excess of water had been removed, was placed in a petri dish and steamed for $10 \mathrm{~min}$ at $1 \mathrm{~atm}$. When cooled, it was inoculated with the spores of an aspergillus and incubated generally for $40 \mathrm{hr}$ at $32^{\circ}$, with occasional shaking $20 \mathrm{hr}$ after the inoculation. Certain strains belonging to the A. parasiticus group were incubated for further 10 to $20 \mathrm{hr}$ at the same temperature owing to their slow growth on rice.

The appearance of most of the kojis made was white but some kojis showed yellow to yellow-green color as the result of spore formation.

Fluorometry and thin-layer chromatography (TLC). The prepared rice koji was crushed after drying, extracted with chloroform, and treated with petroleum ether and chloroform as in the previous work (2). The chloroform solution $(10 \mathrm{ml})$ was divided into two equal parts. One part (corresponding to 40 grams of rice) was analyzed by a fluorometer and the other was subjected to TLC by the same method as reported previously.

Identification of spots in TLC by UV absorption and fluorescence spectra. Thirteen strains important from aflatoxin productivity, as well as strain ATCC 15517, were incubated stationarily for 10 days at $32^{\circ}$ in 2 liters of the ADYE and MATELES' medium (3) in a 5-liter Fernbach flask and/or for $45 \mathrm{hr}$ at $32^{\circ}$ on $1 \mathrm{~kg}$ of steamed rice in a large petri dish, stirring occasionally; the culture medium for each strain was selected from the results of the previous smaller-scale experiments. The chloroform solution containing fluorescent substances was prepared similarly as before.

Sixty to eighty chromatoplates were prepared for the same chloroform solution of each strain in order to obtain as larger an amount of the spotsubstance as possible. Each of the spots collected was extracted with $99 \%$ methanol, the extract was quickly evaporated to dryness under a reduced pressure, and the residue was again dissolved in $99 \%$ ethanol. The ethanol solution of each spot of each strain thus obtained was analyzed with a Hitachi model EPS-2 spectrophotometer and then, after evaporating the ethanol solution to dryness and dissolving the residue in chloroform, with a Hitachi model MPF-2 spectrofluorophotometer.

\section{RESULTS AND DISCUSSION}

\section{Difference of fuorescence spectrum.}

The fluorescence spectra of the chloroform solution from the rice kojis of strain ATCC 15517 and a representative yellow green-spored aspergillus and from the polished rice used as a control are shown in Figs. 1, 2, and 3, 


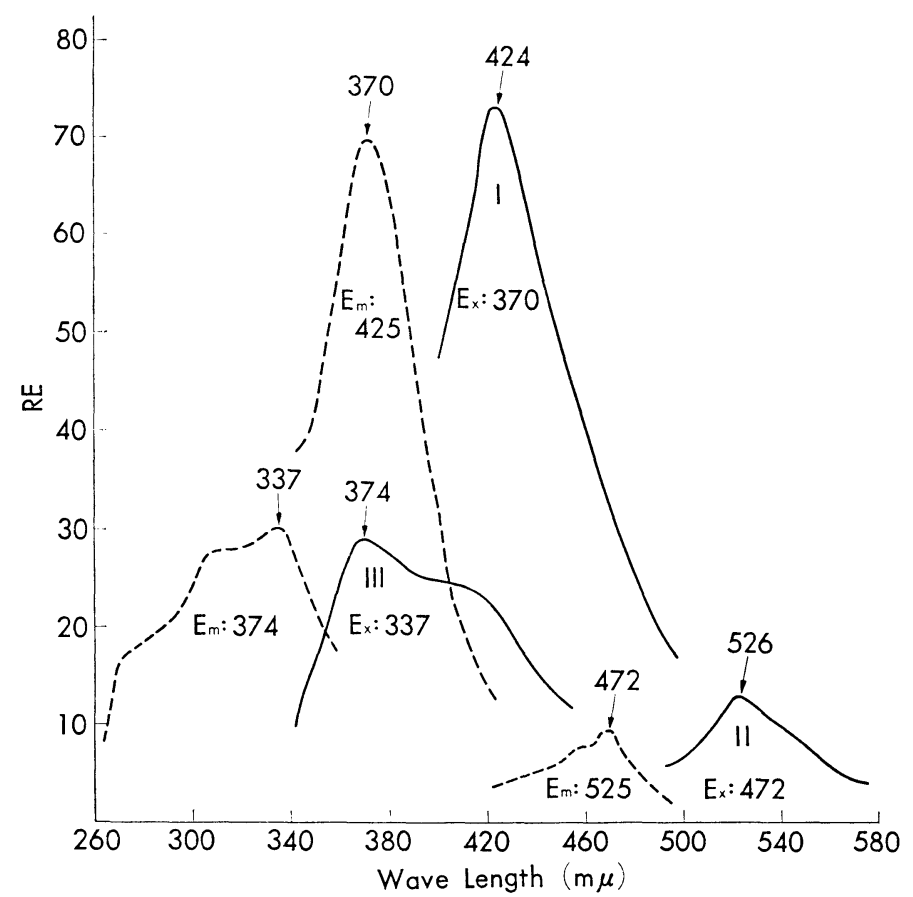

Fig. 1. Fluorescence spectra and three kinds of peak (I, II and III) of the rice koji cultured with strain ATCC 15517.

Abbreviations and signs used in Figs. 1, 2 and 3 are the same as those in Part 1.

_ emission curve -..- excitation curve

respectively. Generally they were similar to those obtained in the shaking culture experiment reported in Part 1 and usually had three peaks (I, II, and III).

For the yellow green-spored aspergilli, the ranges of variation of excitation and emission maxima, and of fluorescence intensity could be summarized as presented in Table 1 (those of some strains belonging to other groups of Aspergillus deviated from the ranges given in the table). The distributions of excitation and emission maxima in blue and green fluorescences (Peaks I and II) are shown in Figs. 4 and 5, respectively. In blue fluorescence a few strains had excitation and emission maxima similar to those of strain ATCC 15517, and, in green fluorescence, many strains had the similar values. The distributions of fluorescence intensity in Peaks I and II are tabulated in Table 2. Nineteen strains in blue fluorescence and 10 strains in green fluorescence had the same or stronger fluorescence intensity than that of strain ATCC 15517. 


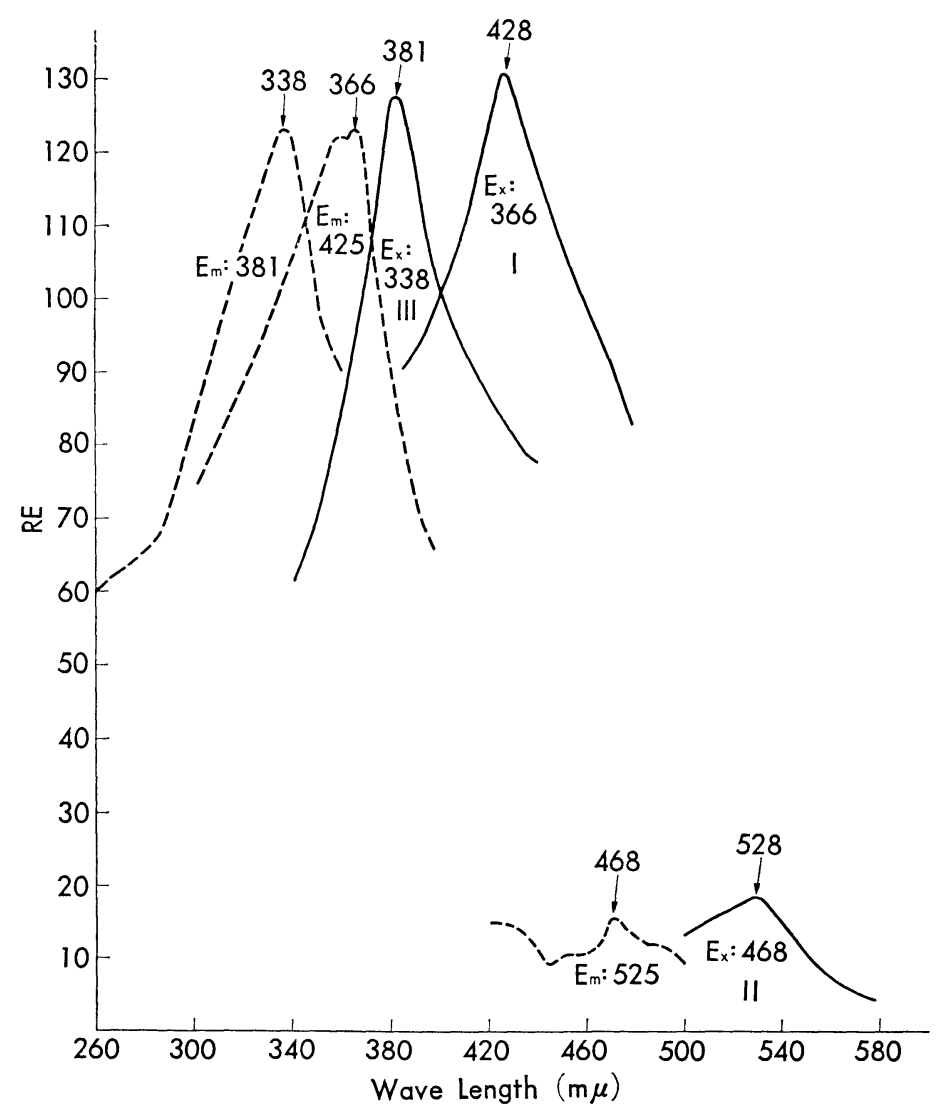

Fig. 2. Fluorescence spectra and three kinds of peak (I, II and III) of the rice koji cultured with a representative yellow green-spored Aspergillus, RIB 301.

In comparing the intensities of fluorescent substances produced in $40 \mathrm{~g}$ of rice koji with those produced in $40 \mathrm{ml}$ of the ADYE and MATELEs' medium reported previously, the former were usually weaker than the latter in both blue and green fluorescences. Some strains, therefore, did not produce any fluorescent substance in rice koji.

\section{Thin-layer chromatography.}

The chromatographic patterns of the chloroform solutions from rice kojis were generally similar to those from the culture solutions in the ADYE and MATELES'medium; however, most of the spots were smaller in size and weaker in fluorescence. In the former, relatively many strains had spot $B_{b}$ 


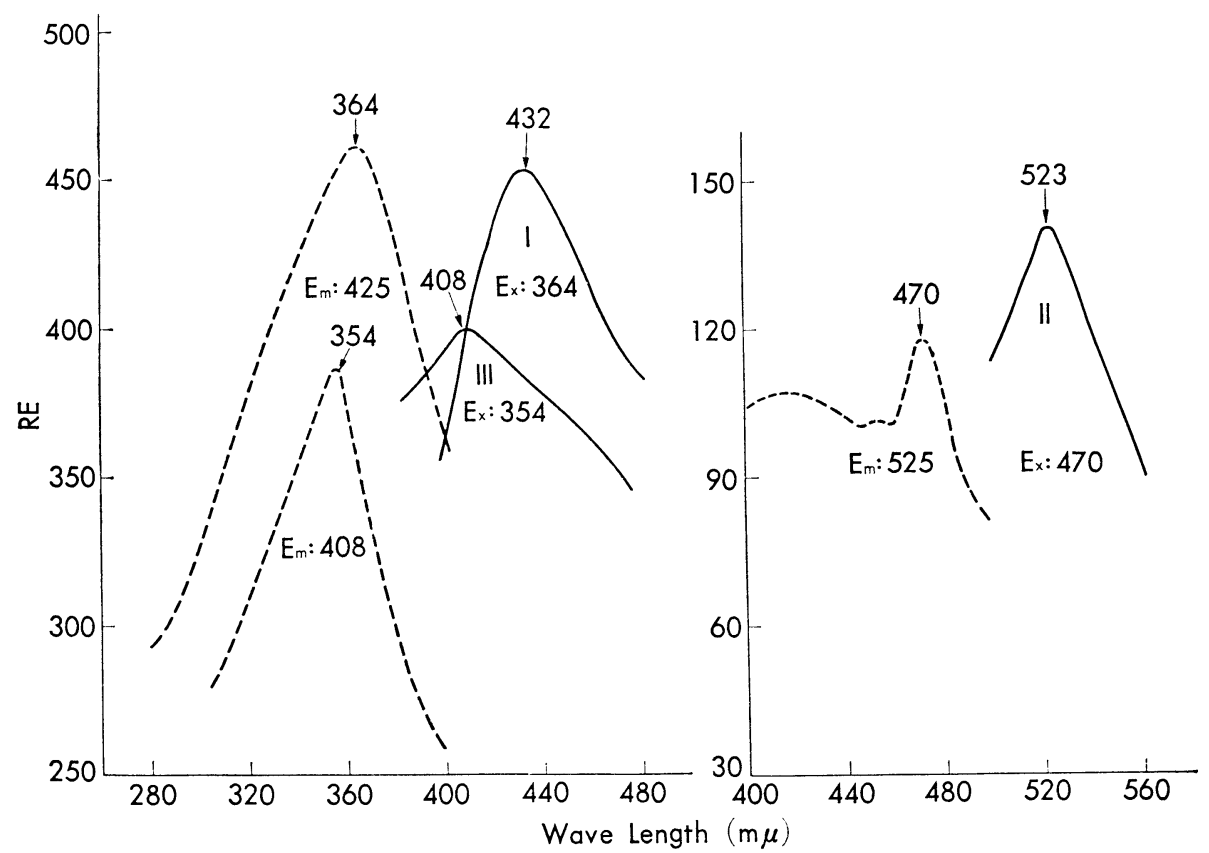

Fig. 3. Fluorescence spectra and three kinds of peak (I, II and III) of the polished rice.

Table 1. Ranges of variation of excitation and emission maxima, and of fluorescence intensity of the yellow green-spored Aspergillus.

(Rice koji)

\begin{tabular}{|c|c|c|c|}
\hline & & $\begin{array}{l}\text { Blue fluorescence } \\
\text { (Peak I) }(\mathrm{m} \mu)\end{array}$ & $\begin{array}{l}\text { Green fluorescence } \\
\quad(\text { Peak II })(\mathrm{m} \mu)\end{array}$ \\
\hline \multirow{3}{*}{ Strain ATCC 15517} & $\mathrm{E}_{\mathrm{x}}$ & $\begin{array}{c}368-372 \\
(370)\end{array}$ & $\begin{array}{c}470-474 \\
(475)\end{array}$ \\
\hline & $\mathrm{E}_{\mathrm{m}}$ & $\begin{array}{c}422-426 \\
(430)\end{array}$ & $\begin{array}{c}524-526 \\
(545)\end{array}$ \\
\hline & $\mathrm{RE}$ & $70-80$ & $10-12$ \\
\hline \multirow{3}{*}{ Yellow-green strains } & $\mathrm{E}_{\mathrm{x}}$ & $313-370$ & $468-478$ \\
\hline & $\mathrm{E}_{\mathrm{m}}$ & $385-438$ & $510-534$ \\
\hline & $\mathrm{RE}$ & $0-140$ & $0-26$ \\
\hline
\end{tabular}

Abbreviations used are the same as those in Part 1 (2).

The RE values are those obtained with $40 \mathrm{~g}$ of polished rice.

Numerals in parentheses are the data obtained by K. Aibara et al. (8).

(cf Table 4 in Part 1) 


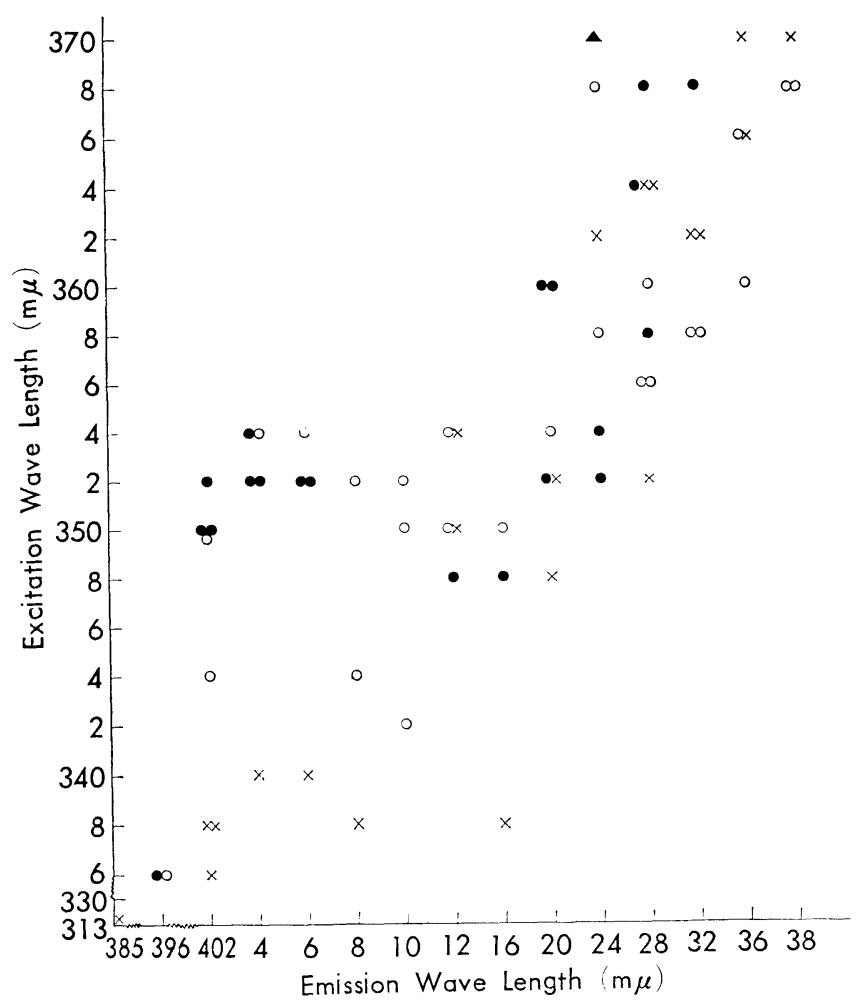

Fig. 4. Distribution of $E_{x}, E_{m}$, and $R E$ of the Peak I (blue fluorescence) for 67 strains of the yellow green-spored Aspergillus.

(Rice koji)

- strains with larger RE than 60

$O$ strains with RE between 40 and 30

$\times$ strains with smaller RE than 30

A strain ATCC 15517

and $G_{b}$, and ten strains of the yellow green-spored aspergilli had spot $B_{a}$, while none had spot $G_{a}$ (spots $B_{b}, G_{b}, B_{a}$ and $G_{a}$ correspond to spots $B_{2}, G_{2}$, $B_{1}$ and $G_{1}$ of aflatoxin, respectively) (Table 3). In addition, many strains had other yellow-green fluorescent spots or zones on the upper portion of the plate and some other spots on the lower portion ( $c f$ Fig. 5 in Part 1)

The polished rice also had fluorescent substances and showed two to three spots with blue or green fluorescent color on TLC. Therefore, all the results in the rice koji experiments include fluorescent substances in rice koji itself.

Selection of important strains from aflatoxin productivity.

The results of the rice koji experiment not always ran parallel with those 


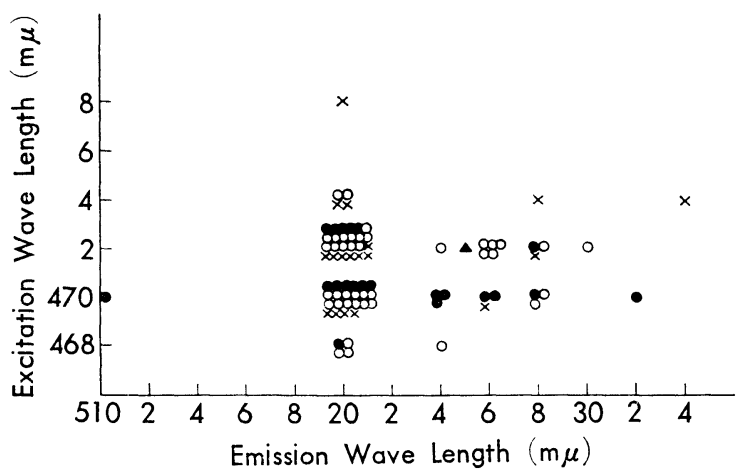

Fig. 5. Distribution of $E_{x}, E_{m}$, and RE of the Peak II (green fluorescence) for 79 strains of the yellow greenspored Aspergillus.

(Rice koji)

- strains with larger RE than 7

strains with RE between 4 and 6

$\times$ strains with smaller RE than 3

A strain ATCC 15517

Table 2. Distribution of strains having various $\mathrm{RE}$ in Peaks $\mathrm{I}$ and II among 82 strains of the yellow green-spored Aspergillus.

\begin{tabular}{|c|c|c|c|c|c|c|c|c|c|c|}
\hline & & & & & & & & \multicolumn{3}{|c|}{ (Rice koji) } \\
\hline \multirow{2}{*}{ Peak I } & $\mathrm{RE}$ & 0 & $\begin{array}{c}\text { below } \\
20\end{array}$ & 30 & 40 & 50 & 60 & $\begin{array}{l}70 \\
\text { to } \\
90\end{array}$ & $\begin{array}{l}90 \\
\text { to } \\
120\end{array}$ & $\begin{array}{c}\text { above } \\
120\end{array}$ \\
\hline & $\begin{array}{c}\text { Number } \\
\text { of } \\
\text { strains }\end{array}$ & 16 & 4 & 17 & 6 & 10 & 10 & 13 & 2 & 4 \\
\hline \multirow{2}{*}{ Peak II } & $\mathrm{RE}$ & 0 & $\begin{array}{c}\text { below } \\
2\end{array}$ & $\begin{array}{r}3 \\
\text { to } \\
4\end{array}$ & $\begin{array}{r}5 \\
\text { to } \\
6\end{array}$ & $\begin{array}{r}7 \\
\text { to } \\
8\end{array}$ & $\begin{array}{r}9 \\
\text { to } \\
10\end{array}$ & $\begin{array}{l}11 \\
\text { to } \\
16\end{array}$ & $\begin{array}{l}19 \\
\text { to } \\
20\end{array}$ & 26 \\
\hline & $\begin{array}{c}\text { Number } \\
\text { of } \\
\text { strains }\end{array}$ & 3 & 7 & 22 & 29 & 11 & 5 & 3 & 1 & 1 \\
\hline
\end{tabular}

of the previous shaking culture experiment using the ADYE and MATELES' medium. The strain distributions for some important characters in the two experiments are compared in Table 3 . It is clear that some strains produced the blue fluorescence spectrum and the spot $B_{a}$ like aflatoxin producer in rice koji, rather than in shaking culture, while considerable number of other strains lacked any fluorescence or spot in rice koji. Considering these facts, 
Table 3. Percentage of strains having various important characters from aflatoxin productivity.

(Shaking culture and rice koji)

\begin{tabular}{|c|c|c|c|}
\hline Character of fungi & $\begin{array}{l}\text { Method } \\
\text { of } \\
\text { culture }\end{array}$ & $\begin{array}{l}\text { Yellow } \\
\text { green } \\
\text { strains } \\
(\%)\end{array}$ & $\begin{array}{c}\text { Other } \\
\text { strains } \\
(\%)\end{array}$ \\
\hline Absence of blue fluorescence (Peak I) & $\begin{array}{l}\text { Shaking } \\
\text { Koji }\end{array}$ & $\begin{array}{r}0.0 \\
19.3\end{array}$ & $\begin{array}{l}0.0 \\
0.0\end{array}$ \\
\hline Absence of green fluorescence (Peak II) & $\begin{array}{l}\text { Shaking } \\
\text { Koji }\end{array}$ & $\begin{array}{l}0.0 \\
5.0\end{array}$ & $\begin{array}{l}7.8 \\
0.0\end{array}$ \\
\hline No spots in TLC & $\begin{array}{l}\text { Shaking } \\
\text { Koji }\end{array}$ & $\begin{array}{r}8.5 \\
23.7\end{array}$ & $\begin{array}{r}5.2 \\
25.0\end{array}$ \\
\hline Presence of aflatoxin-like $E_{x}$ in Peak $I$ & $\begin{array}{l}\text { Shaking } \\
\text { Koji }\end{array}$ & $\begin{array}{l}0.0 \\
3.7\end{array}$ & $\begin{array}{l}21.0 \\
33.0\end{array}$ \\
\hline Presence of aflatoxin-like $E_{x}$ and $E_{m}$ in Peak $I$ & $\begin{array}{l}\text { Shaking } \\
\text { Koji }\end{array}$ & $\begin{array}{l}0.0 \\
1.9\end{array}$ & $\begin{array}{l}2.6 \\
8.3\end{array}$ \\
\hline Presence of aflatoxin-like $E_{x}$ and $E_{m}$ in Peak II & $\begin{array}{l}\text { Shaking } \\
\text { Koji }\end{array}$ & $\begin{array}{l}34.5 \\
15.4\end{array}$ & $\begin{array}{l}32.4 \\
75.0\end{array}$ \\
\hline $\begin{array}{l}\text { Having larger } \mathrm{RE} \text { in Peak I than } 1,000 \\
\text { Having larger RE in Peak I than } 100\end{array}$ & $\begin{array}{l}\text { Shaking } \\
\text { Koji }\end{array}$ & $\begin{array}{l}3.9 \\
3.7\end{array}$ & $\begin{array}{r}2.6 \\
16.0\end{array}$ \\
\hline $\begin{array}{l}\text { Having larger RE in Peak II than } 30 \\
\text { Having larger } R E \text { in Peak II than } 10\end{array}$ & $\begin{array}{l}\text { Shaking } \\
\text { Koji }\end{array}$ & $\begin{array}{l}4.5 \\
3.1\end{array}$ & $\begin{array}{l}15.7 \\
25.0\end{array}$ \\
\hline Presence of $B_{a}$ spot & $\begin{array}{l}\text { Shaking } \\
\text { Koji }\end{array}$ & $\begin{array}{l}3.9 \\
6.2\end{array}$ & $\begin{array}{l}5.2 \\
0.0\end{array}$ \\
\hline Presence of $\mathrm{G}_{\mathrm{a}}$ spot & $\begin{array}{l}\text { Shaking } \\
\text { Koji }\end{array}$ & $\begin{array}{l}2.8 \\
0.0\end{array}$ & $\begin{array}{r}13.1 \\
0.0\end{array}$ \\
\hline Presence of both $B_{a}$ and $G_{a}$ spots & $\begin{array}{l}\text { Shaking } \\
\text { Koji }\end{array}$ & $\begin{array}{l}2.3 \\
0.0\end{array}$ & $\begin{array}{l}2.6 \\
0.0\end{array}$ \\
\hline Presence of both $B_{b}$ and $G_{b}$ spots & $\begin{array}{l}\text { Shaking } \\
\text { Koji }\end{array}$ & $\begin{array}{l}85.0 \\
35.0\end{array}$ & $\begin{array}{l}58.2 \\
22.3\end{array}$ \\
\hline Increase in number of spots by koji-making & Shaking & 7.5 & 8.3 \\
\hline Total number of strains tested & $\begin{array}{l}\text { Shaking } \\
\text { Koji }\end{array}$ & $\begin{array}{l}176 \\
160\end{array}$ & $\begin{array}{l}38 \\
12\end{array}$ \\
\hline
\end{tabular}


13 strains having at least one of the following characters were selected for further studies; by comparison with those of strain ATCC 15517, similar excitation and emission maxima in fluorescence spectra, stronger relative intensity of fluorescence, and similar spots in TLC. The principal character-

Table 4. Principal characters of 13 important strains.

\begin{tabular}{|c|c|c|c|}
\hline \multirow{2}{*}{$\begin{array}{l}\text { Group } \\
\text { of } \\
\text { species } \\
\text { name }\end{array}$} & \multirow{2}{*}{$\begin{array}{l}\text { Strain } \\
\text { No. }\end{array}$} & \multicolumn{2}{|c|}{$\begin{array}{l}\text { Fluorescent color and intensity (in parentheses }{ }^{x} \text { ), } \\
\text { and the presence of aflatoxin-like spots }\end{array}$} \\
\hline & & Liquid culture & Rice koji \\
\hline \multirow{5}{*}{$\begin{array}{l}\text { A. flavus } \\
\text { and } \\
\text { A. oryzae }\end{array}$} & RIB 216 & blue (140), green (11) & blue (132), green (10) \\
\hline & RIB 218 & blue (116), green (12) & blue (204), green $(30)$ \\
\hline & RIB 301 & $\begin{array}{l}\text { blue }(3,312) \text {, green }(46) \\
\mathrm{B}_{\mathrm{a}} \text { and } \mathrm{G}_{\mathrm{a}} \text { spots }\end{array}$ & blue (132), green (19) \\
\hline & RIB 329 & blue (272), green (21) & blue $(140)$, green $(26)$ \\
\hline & RIB 331 & blue $(10,944)$, green $(250)$ & blue (100), green ( 6$)$ \\
\hline \multirow{3}{*}{ A. parasiticus } & RIB 401 & blue (608), green (60) & blue (44), green (5) \\
\hline & RIB 405 & blue (120), green (16) & $\begin{array}{l}\text { blue } \mathrm{E}_{\mathrm{x} \mathrm{Afla}^{b}} \text { and } \mathrm{E}_{\mathrm{m} \mathrm{Afla}}{ }^{b} \\
(55), \quad \text { green }(6) ; \mathrm{B}_{\mathrm{a}} \text { spot }\end{array}$ \\
\hline & RIB 410 & blue (192), green (23) & blue $\mathrm{E}_{\mathrm{x} \text { Afla }}(64)$, green (9) \\
\hline A. nigerc & IAM 3008 & blue (672), green (21) & blue $(2,112)$, green $(76)$ \\
\hline A. niger & RIB 2003 & $\begin{array}{l}\text { green }(52), \mathrm{G}_{\mathrm{a}} \text { spot; } \\
\text { deviated } \mathrm{E}_{\mathrm{x}}\end{array}$ & \\
\hline A. niger ${ }^{d}$ var. & RIB 2503 & $\begin{array}{l}\text { blue (168), green (108); } \\
\text { deviated } \mathrm{E}_{\mathrm{x}}\end{array}$ & blue (45), green $(6)$ \\
\hline A. awamori & RIB 2805 & $\mathrm{~B}_{\mathrm{a}}$ and $\mathrm{G}_{\mathrm{a}}$ spots & \\
\hline A. terreus & IAM 2179 & $\begin{array}{l}\text { blue }(11,136), \text { green }(0) \\
\mathrm{B}_{\mathrm{a}} \text { and } \mathrm{G}_{\mathrm{a}} \text { spots }\end{array}$ & $\begin{array}{l}\text { blue } E_{x} \text { Afla and } E_{m \text { Afla }} \\
(28), \text { green }(3)\end{array}$ \\
\hline ATCC 15517 & RIB 4001 & $\begin{array}{l}\text { blue }(9,000-11,000) \text {, } \\
\text { green }(80-100)\end{array}$ & $\begin{array}{l}\text { blue }(70-80) \\
\text { green }(10-12)\end{array}$ \\
\hline
\end{tabular}

$a$ The values of fluorescent intensity are those obtained with the shaking culture or with rice koji, corresponding $40 \mathrm{ml}$ of the ADYE and MATELEs' medium or $40 \mathrm{~g}$ of polished rice, respectively.

${ }_{b} E_{\mathrm{x} \text { Afla }}$ and $\mathrm{E}_{\mathrm{m} \mathrm{Afla}}$ : excitation and emission maxima similar to those of aflatoxin, respectively.

$c$ Increased the number of spots with rice koji as compared with the case with the ADYE and MATELES' medium.

d A. niger var. RIB 2503 characteristically formed an orange fluorescent spot. 
istics of these strains are summarized in Table 4 .

UV absorption spectra of the spots of strain ATCC 15517.

The absorption spectra of the spots of strain ATCC 15517 obtained by TLC using 60 to 80 chromatoplates, in concentrated or diluted ethanol solutions, are shown in Figs. 6 and 7 . There were three or four absorption

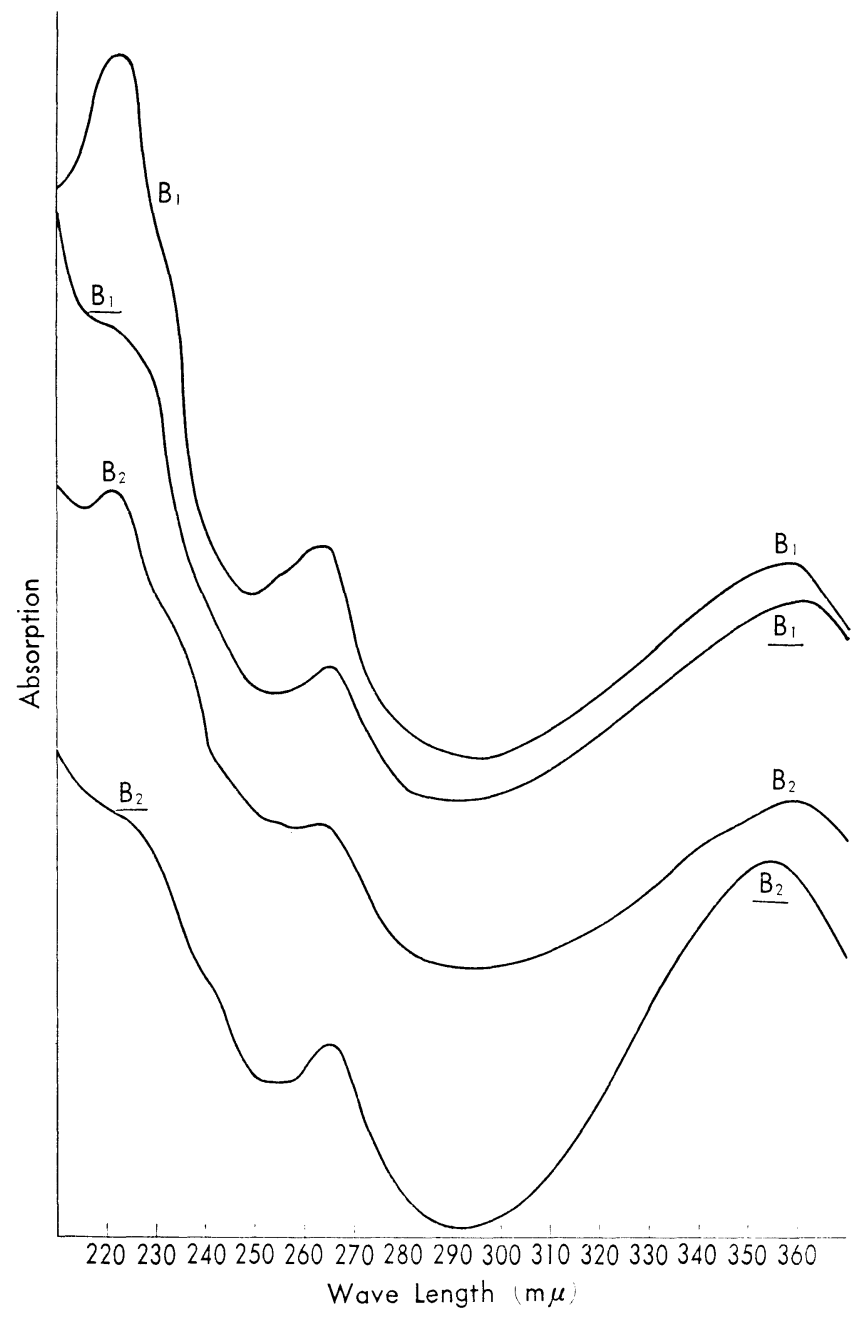

Fig. 6. Change of UV absorption spectra of aflatoxin B by its concentration.

$B_{1}$ and $B_{2}$, saturated ethanol solution of aflatoxins $B_{1}$ and $B_{2}$, respectively. $\underline{B_{1}}$ and $\underline{B_{2}}$, those diluted 100 -fold. 
$\operatorname{maxima}\left(\lambda_{\max }\right), 223,265$ and $362 \mathrm{~m} \mu$ in $\mathrm{B}_{1}$ and $\mathrm{B}_{2}$, and $243,257,264$, and $362 \mathrm{~m}^{\prime} \mu$ in $\mathrm{G}_{1}$ and $\mathrm{G}_{2}$, which were identified with those of the authentic data. Some of the absorption maxima, e.g., 223, 243 and $257 \mathrm{~m} \mu$, sometimes disappeared either in a low concentration or in a sample obtained by the repetition of TLC, as seen in Figs. 6 and 7. Therefore, the lack of these absorption maxima may not mean the absence of aflatoxin. At any rate, the presence of aflatoxins must be tested by the absorption maxima at both 265 and 362 "m $"$.

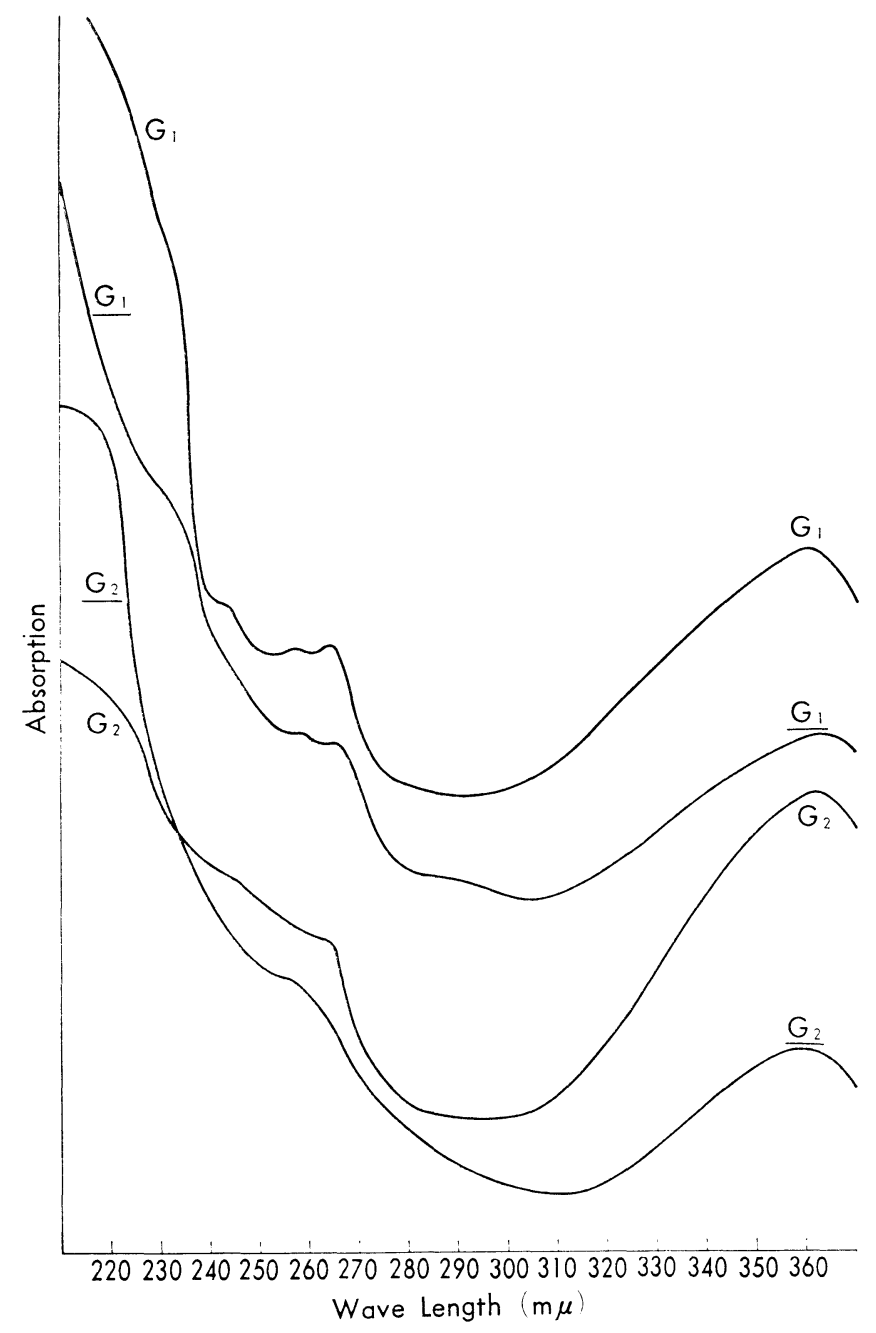

Fig. 7. Change of UV absorption spectra of aflatoxin G by its concentration.

Abbreviations used are the same as those in Fig. 6. 
Incidentally, SARGEANT et al. (4) reported the absorption maxima of aflatoxin $\mathrm{B}$ to be at 223,265 , and $363 \mathrm{~m} \mu$, and aflatoxin $\mathrm{G}$ at 265 and $363 \mathrm{~m} \varphi$. LEE et al. (5) used the absorption maxima at $362 \mathrm{~m}^{\prime \prime}$ in searching for aflatoxins $\mathrm{B}$ and $\mathrm{G}$.

\section{$U V$ absorption spectra of the spots of the important strains.}

Fig. 8 shows the absorption spectra of the ethanol extracts of representative spots, obtained from TLC of the 13 important strains, which were classified into nine patterns (designated as Pattern I to IX). The absorption maxima

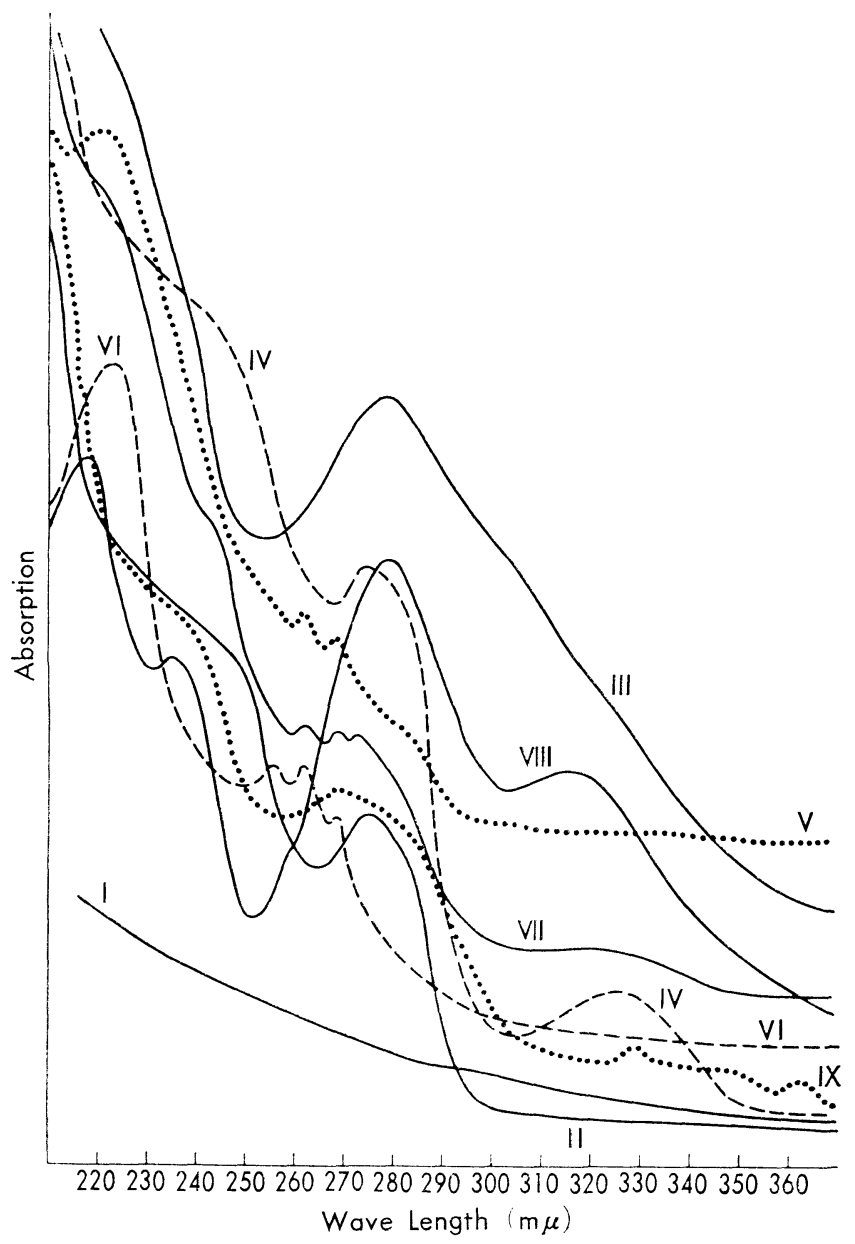

Fig. 8. Nine kinds of pattern of UV absorption spectra shown by the important strains. (Ethanol solution) 
Table 5. Classification of the spot-substances of 13 important strains by UV absorption spectra.

Nine kinds of pattern with different absorption maxima, and number of spots associated with each pattern

\begin{tabular}{|c|c|c|c|c|c|c|c|c|c|c|c|c|}
\hline \multirow{3}{*}{$\begin{array}{l}\text { Strain } \\
\text { No. }\end{array}$} & \multirow{3}{*}{$\begin{array}{l}\text { Method } \\
\text { of } \\
\text { culture }\end{array}$} & \multicolumn{11}{|c|}{$\begin{array}{l}\text { Nine kinds of pattern with different absorption maxima, and } \\
\text { number of spots associated with each pattern }\end{array}$} \\
\hline & & I & II & III & IV & $\mathrm{V}$ & $\mathrm{VI}$ & VII & VIII & IX & Afla & toxin \\
\hline & & none & $\begin{array}{l}275 \\
\mathrm{~m} !\end{array}$ & $\begin{array}{l}280 \\
\mathrm{~m} \varphi\end{array}$ & $\begin{array}{l}275 \\
326 \\
\mathrm{~m} !\end{array}$ & $\begin{array}{l}223 \\
262 \\
268 \\
\mathrm{~m} \mu\end{array}$ & $\begin{array}{l}223 \\
256 \\
262 \\
268 \\
\mathrm{~m} \mu\end{array}$ & $\begin{array}{l}262 \\
268 \\
273 \\
\mathrm{~m} /\end{array}$ & $\begin{array}{l}218 \\
235 \\
280 \\
317 \\
\mathrm{~m} !\end{array}$ & $\begin{array}{l}268 \\
328 \\
364 \\
\mathrm{~m} / \ell\end{array}$ & $\begin{array}{c}\mathrm{B} \\
223 \\
265 \\
362 \\
\mathrm{~m} \mu\end{array}$ & $\begin{array}{c}\mathrm{G} \\
\\
243 \\
257 \\
264 \\
362 \\
\mathrm{~m} !^{\prime \prime}\end{array}$ \\
\hline RIB 216 & Koji & & $3^{*}$ & & & & $1 \mathrm{~b}$ & & & & & \\
\hline RIB 218 & Koji & & 1 & & & & & & & & & \\
\hline \multirow{2}{*}{ RIB 301} & Liquid & & 5 & & & & & & & & & \\
\hline & Koji & & 5 & & & & & & & & & \\
\hline \multirow{2}{*}{ RIB 329} & Liquid & & 5 & & & & & & & & & \\
\hline & Koji & $1 \mathrm{bw}$ & 3 & & & & & & & & & \\
\hline \multirow{2}{*}{ RIB 331} & Liquid & & 4 & & $1 \mathrm{yg}$ & & & & & $1 \mathrm{~b}$ & & \\
\hline & Koji & $1 \mathrm{bw}$ & $\bar{j}$ & & & & & & & & & \\
\hline RIB 401 & Liquid & & 7 & & & & $1 \mathrm{~b}$ & & & & & \\
\hline RIB 405 & Koji & & 7 & & & & & & & & & \\
\hline RIB 410 & Koji & & 7 & & & & & & & & & \\
\hline IAM 3008 & Koji & & 7 & & & & & & & & & \\
\hline RIB 2003 & Liquid & $1 \mathrm{bw}$ & 3 & $1 \mathrm{~g}$ & & $1 \mathrm{~g}$ & & $2 g$ & $1 \mathrm{~g}$ & & & \\
\hline RIB 2503 & Liquid & & 7 & $2 \mathrm{~g}$ & & & & $1 \mathrm{~g}$ & $1 \mathrm{~g}$ & & & \\
\hline RIB 2805 & Liquid & $1 \mathrm{bw}$ & 5 & & & $1 \mathrm{~g}$ & $1 \mathrm{~b}$ & & & & & \\
\hline IAM 2179 & Liquid & & $\overline{5}$ & & & & & & & & & \\
\hline $\begin{array}{l}\text { ATCC } \\
15517\end{array}$ & $\begin{array}{l}\text { Liquid } \\
\text { Koji }\end{array}$ & & & & & & & & & & $\begin{array}{l}2 b \\
2 b\end{array}$ & $\begin{array}{l}2 \mathrm{~g} \\
2 \mathrm{~g}\end{array}$ \\
\hline
\end{tabular}

Abbreviation: b, blue. bw, bluish white. yg, yellow-green. g, green.

* The fluorescent color is not shown in the column of Pattern II. 
of each pattern are shown in Table 5 , together with number of spots belonging to each pattern; the Pattern II was shared by one to seven spots.

The Pattern IX obtained from the shaking culure of strain RIB 331 is considered to be highly similar to the pattern of aflatoxin if an experimental error of $\pm 3 \mathrm{~m}^{\prime \prime}$ is permitted and if absorption maxima at $328 \mathrm{~m} !$ ! is neglected ; however, absorption maxima at $364 \mathrm{~m} ! !$ is far smaller than that of aflatoxin, as seen in Fig. 8.

Thus, though the spot substances were not isolated chemically in these experiments, at least it can safely be said that the UV absorption spectra of the fluorescent spots of all the industrial strains of Aspergillus were distinctly differed from those of aflatoxins.

YOKOTSUKA et al. $(6,7)$ already studied the fluorescent substances of about 60 industrial strains, using different culture medium and preparation method from those of the present authors'. They classified the UV absorption spectra of the spots into six patterns; three of which agree with the Patterns I, II, and IV, and the rest do not agree with any of our patterns (all of the latter had absorption maxima at 310 to $320 \mathrm{~m}^{\prime \prime}$ ). In addition, they determined the chemical structure of some of the fluorescent substances. In their experiments, the aflatoxin production was not demonstrated.

The authors wish to express their thanks to Messrs. H. Sagawa, S. Hyoto, Y. Ikeda, S. Doi, K. Ninchoji, T. Shimazaki, and Y. Takahashi of this Institute for their technical assistance on thin-layer chromatography.

\section{REFERENCES}

1) O.L. Shotwell, C.W. Hesseltine, R.D. Stubblefield and W.G. Sorenson, Appl. Microbiol., 14, 425 (1966).

2) H. Murakami, S. Takase and T. Ishit, J. Gen. Appl. Microbiol., 13, 323 (1967).

3) J. Adye and R.I. Mateles, Biochim. Biophys. Acta, 86, 418 (1964).

4) K. Sargeant, R.B.A. Carnaghan and R. Allcroft, Chem. Ind. (London), 53 (1963).

5) E.G.H. Lee, P.M. Townsley and C.C. Walden, J. Food Sci., 31, 432 (1966).

6) T. Yokotsuka, M. Sasaki, T. Kikuchi, Y. Asao and A. Nobuhara, J. Agr. Chem. Soc. Japan, 41, 32 (1967).

7) M. Sasaki, T. KikUchi, Y. Asao and T. Yokotsuka, ibid., 154.

8) K. Aibara and K. Miyaki, Proc. 40 Ann. Meet. Agr. Chem. Soc. Japan, p. 86, (1965) (abstract in Japanese). 